\title{
Biochar as a Soil Ameliorant: How Biochar Properties Benefit Soil Fertility-A Review
}

\author{
Christine Beusch \\ Institute of Ecology, Chair of Soil Science, Technische Universität Berlin, Berlin, Germany \\ Email: christine.beusch@email.de
}

How to cite this paper: Beusch, C. (2021). Biochar as a Soil Ameliorant: How Biochar Properties Benefit Soil Fertility-A Review. Journal of Geoscience and Environment Protection, 9, 28-46.

https://doi.org/10.4236/gep.2021.910003

Received: September 8, 2021

Accepted: October 16, 2021

Published: October 19, 2021

Copyright $\odot 2021$ by author(s) and Scientific Research Publishing Inc. This work is licensed under the Creative Commons Attribution International License (CC BY 4.0).

http://creativecommons.org/licenses/by/4.0/

\begin{abstract}
In recent years, biochar has received great attention among researchers worldwide. This carbon-rich material, mainly produced from residues from agriculture and forestry, holds a wide range of properties, e.g. large specific surface area, high cation exchange capacity, and substantial nutrient contents, that can have beneficial effects when added to soils. This review is giving a brief introduction to biochar properties and how feedstock, pyrolysis temperature, and time influence these properties. As the majority of studies concentrate on the soil amending effects of biochar, this review also provides an overview of how biochar affects the chemical, physical, hydrological, and biological properties of soils. For example, biochar addition to soils can raise the $\mathrm{pH}$, increase the organic carbon content, enhance nutrient retention, foster porosity, augment the water-holding capacity, and increase microbial biomass. Consequently, biochar can contribute to soil fertility, increase yields, help closing nutrient cycles, and thus help secure food safety in a region. However, the knowledge about the long-term effects is still limited and should be broadened by a more systematic testing of biochar effects in the future to help bring the benefits of biochar into practice.
\end{abstract}

\section{Keywords}

Biochar, Soil Amendment, Feedstock, Pyrolysis Temperature, Soil Fertility

\section{Introduction}

Biochar is a solid and carbon-rich material produced by pyrolysis of biomass in a low oxygen (O) environment (Joseph et al., 2010; Lehmann \& Joseph, 2015; Solaiman \& Anawar, 2015; Wang et al., 2016). The term "biochar" was introduced in 2006 by Lehmann et al., specifying charcoal used for environmental 
purposes and in particular to maintain or improve soil fertility.

Since the mid-1990s, Anthropogenic Dark Earths or terra preta de Índio soils located in the Central Amazon received growing attention in soil research (Lehmann et al., 2003; Neves et al., 2004). These relict Anthrosols have been heavily modified by pre-Columbian settlers by the addition of several inorganic and organic materials, e.g. charcoal, ash, bones, biomass waste, manure, faeces, and urine (Glaser \& Birk, 2012). Radiocarbon data revealed ages of the analysed soil samples ranging from 350 to 2310 years BP (Neves et al., 2004). Other than the relatively poor soils in their direct vicinity, terra preta soils exhibit large stocks of stable organic matter and high nutrient levels that facilitate agricultural use (Glaser et al., 2001; Glaser \& Birk, 2012). These favourable soil properties still persist despite challenging conditions of the humid tropics (Lehmann et al., 2003). Inspired by these findings, the interest in charcoal application to improve soils is growing worldwide. Since 2008, the number of scientific articles about biochar application started to increase (Lehmann et al., 2015), reaching a total of 6934 scientific publications in late 2018 (Wu et al., 2019).

The objectives of this review are 1) to provide a condensed overview of the state-of-the-art knowledge of the factors that control biochar properties, 2) to summarise the effects of biochar addition on soil properties and soil fertility, and 3 ) to suggest future directions to help bring the benefits of biochar into practice.

\section{Methods}

This review is based on an extensive literature research via Science Direct and Google Scholar. The author searched for the key words "biochar and soil and amendment" and selected the literature relevant for this review.

\section{Biochar Properties}

\subsection{General Properties}

Biochars are usually produced from agricultural and forestry residues, or municipal, green, and food waste (Ippolito et al., 2020). The pyrolysis of the original feedstock transforms carbon into a recalcitrant form with a high degree of aromatisation that may persist in soils hundreds to thousands of years (Wang et al., 2016). In general, biochars are of alkaline $\mathrm{pH}$ due to high inorganic carbonate and ash content (Yuan et al., 2011) with a large specific surface area (SSA) and high pore volume (Cheng et al., 2018; Laird et al., 2010; Suliman et al., 2016; Zhao et al., 2013). They also have a high cation exchange capacity (CEC) (Liang et al., 2006) and can develop positive and negative surface charges (Cheng et al., 2008; Liang et al., 2006) that may attenuate leaching of cationic and anionic nutrients when applied to soils (e.g. Agegnehu et al., 2015; Beusch et al., 2019; Knowles et al., 2011; Sika \& Hardie, 2014; Zheng et al., 2013). Biochars may also exhibit substantial amounts of a variety of nutrients, however, this and numerous other physicochemical biochar properties largely depend on feedstock and pyrolysis conditions (Ippolito et al., 2020; Zhao et al., 2013). 


\subsection{Influence of Feedstock Type on Biochar Properties}

Feedstock plays a crucial role for biochar properties and composition. Original feedstock properties like structure and nutrient content are reflected in the pyrolysed end product and determine the characteristics of biochars (Zhao et al., 2013). Wood biochar for example inherits the xylem structure of the parent material, whereas chicken manure biochar has a more heterogeneous structure based on the the components of the manure, like straw, digested food, and feathers (Downie et al., 2009; Ippolito et al., 2020; Joseph et al., 2010).

Lignocellulosic feedstocks, like wood, crop, and herbaceous material, consist of varying ratios of lignin, hemicellulose, and cellulose (Fawzy et al., 2021). Biochars produced from lignin-rich feedstock tend to have higher $\mathrm{C}$ contents with a more aromatic $\mathrm{C}$ structure, leading to higher long-term stability, higher SSA and porosity, lower $\mathrm{pH}$, lower $\mathrm{CEC}$, and lower nutrient content and availability than biochars produced of herbaceous material and non-lignocellulosic feedstock like manure or biosolids (Das et al., 2021; Ippolito et al., 2020; Fawzy et al., 2021; Gul et al., 2015; Li et al., 2020; Zhao et al., 2013). In a meta-data analysis review comprising approx. 5400 peer-reviewed scientific articles, Ippolito et al. (2020) found that wood-based biochars have the greatest SSA while crop- and grass-based biochars exhibit the greatest CEC. An overview of the biochar properties that are influenced by the lignin content of the original feedstock is given in Figure 1.

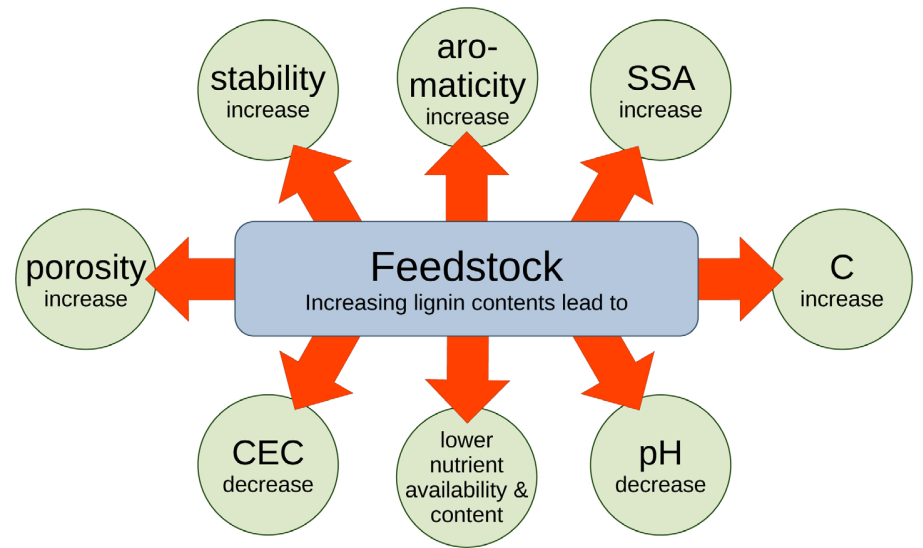

Figure 1. Influence of the lignin content of the feedstock on biochar properties.

Mineral element contents also depend of the type of feedstock (Zhao et al., 2013). During the pyrolysis process, volatile compounds of the biomass like O, hydrogen $(\mathrm{H})$, and sulphur $(\mathrm{S})$ are lost, leading to an accumulation of the non-volatile elements such as $\mathrm{C}$, nitrogen $(\mathrm{N})$, phosphorus $(\mathrm{P})$, potassium $(\mathrm{K})$, calcium $(\mathrm{Ca})$, magnesium $(\mathrm{Mg})$, iron $(\mathrm{Fe})$, and copper $(\mathrm{Cu})$ (Al-Wabel et al., 2013; Ippolito et al., 2020; Zhao et al., 2013).

\subsection{Influence of Pyrolysis Temperature on Biochar Properties}

In their meta-study, Ippolito et al. (2020) identified that pyrolysis type, whether 
fast or slow, only had a marginal influence on biochar properties. Thus, besides feedstock, the pyrolysis temperature plays a decisive role for the physicochemical properties of biochars (Al-Wabel et al., 2013; Das et al., 2021; Ippolito et al., 2020; Zhao et al., 2013). Pyrolysis temperature predominantly controls numerous biochar properties. An overview of the biochar properties that are influenced by the pyrolysis temperature is given in Figure 2 .

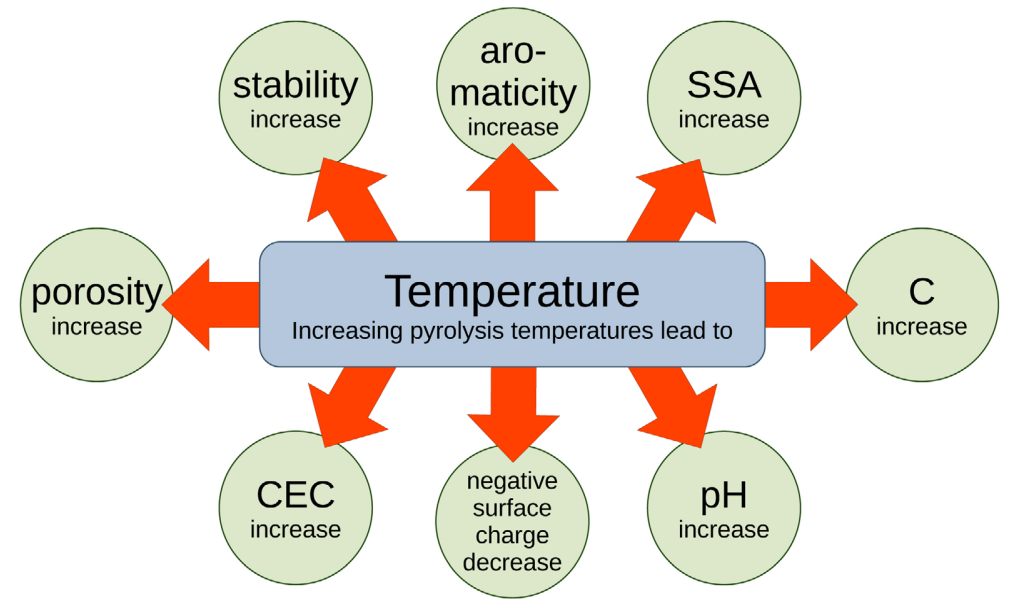

Figure 2. Influence of the pyrolysis temperature on biochar properties.

Greater pyrolysis temperatures lead to an increase of C content, SSA, porosity, $\mathrm{pH}$, alkalinity, inorganic element concentrations, ash content, CEC, and aromaticity (e.g. Al-Wabel et al., 2013; Chen et al., 2019; Downie et al., 2009; Ezepue et al., 2019; Ippolito et al., 2020; Joseph et al., 2010; Yuan et al., 2011; Zhao et al., 2013). The latter accounts for higher recalcitrance and long-term stability of high-temperature biochars with half-lives that exceed 1000 years (Ippolito et al., 2020). With increasing temperature, more volatile components are lost and the biochar yield decreases (Al-Wabel et al., 2013; Yuan et al., 2011). Moreover, higher temperatures foster decomposition of acidic functional groups like phenolic hydroxyl and carboxyl groups, while carbonyl groups form (Chen et al., 2019; Chun et al., 2004; Yuan et al., 2011). Yuan et al. (2011) also reported decreasing zeta potential with increasing pyrolysis temperatures, indicating less negative surface charges for high-temperature biochars than for low-temperature biochars.

\subsection{Influence of Time on Biochar Properties}

Most scientific publications refer to the initial properties of fresh biochars. However, these properties are changing over time when biochars have been exposed to a moisture-containing environment, as it is the case after application to soil. This process is referred to as "ageing". The changes are induced by abiotic and biotic reactions, solubilisation processes, and interactions with organic materials, microbes, minerals, and aqueous phases of the soil (Mia et al., 2017; Mukherjee et al., 2014). In general, ageing processes are enhanced with increasing tempera- 
tures and duration of exposure (Cheng \& Lehmann, 2009) and in particular affect the biochar surface (Cheng \& Lehmann, 2009; Heitkötter \& Marschner, 2015; Liu et al., 2013b; Sorrenti et al., 2016).

After some residence time in soils, the biochar surface is coated and the pores are clogged with organic and mineral components of soils (Joseph et al., 2010; Mukherjee et al., 2014; Ren et al., 2016; de la Rosa et al., 2018; Sorrenti et al., 2016), leading to a decrease of SSA (Ghaffar et al., 2015; Liu et al., 2013b; Mia et al., 2017; Ren et al., 2016) and a reduction of the inner reactive surface (Pignatello et al., 2006). Also biochar $\mathrm{pH}$ is decreasing over time (Cheng \& Lehmann, 2009; Mukherjee et al., 2014; de la Rosa et al., 2018; Sorrenti et al., 2016). While ageing stimulates the development of acidic functional groups (Heitkötter \& Marschner, 2015; Rechberger et al., 2017; de la Rosa et al., 2018; Sorrenti et al., 2016), the concentration of base functional groups on the biochar surface decreases over time (Cheng et al., 2008; Cheng \& Lehmann, 2009). Furthermore, the negative surface charge is increasing with ageing, leading to a high surface charge density and enhanced CEC (Cheng et al., 2008; Heitkötter \& Marschner, 2015; Liang et al., 2006; Mia et al., 2017; Mukherjee et al., 2014), but declining anion exchange capacity (AEC) (Cheng et al., 2008; Lawrinenko et al., 2016). This increase of surface acidity over time indicates that the liming effect of biochars may only persist for a short period of time (de la Rosa et al., 2018). An overview of the biochar properties that are influenced by the pyrolysis temperature is given in Figure 3.

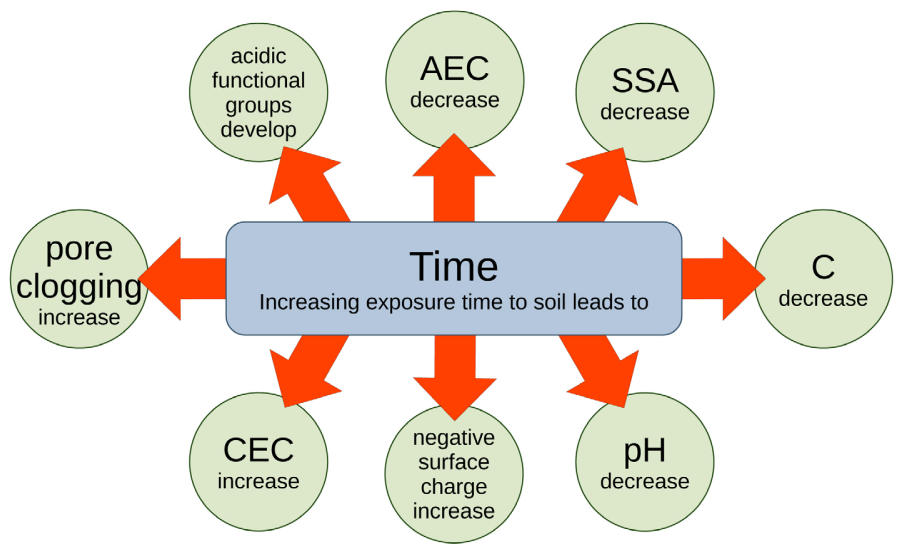

Figure 3. Influence of the exposure time to soil on biochar properties.

In addition, the elemental composition is effected by ageing. Total concentrations of $\mathrm{N}$ and $\mathrm{O}$ increase as well as the atomic concentrations of $\mathrm{O}, \mathrm{S}, \mathrm{N}$, sodium $(\mathrm{Na})$, aluminium $(\mathrm{Al}), \mathrm{Ca}$, manganese $(\mathrm{Mn})$, and Fe detected at the biochar surface, while $\mathrm{C}$ and $\mathrm{K}$ contents decrease (Cheng et al., 2008; Cheng \& Lehmann, 2009; Ghaffar et al., 2015; Mia et al., 2017; de la Rosa et al., 2018; Sorrenti et al., 2016). In particular, the changes in the surface chemistry may alter the adsorption properties of aged biochars (Cheng \& Lehmann, 2009; Ghaffar et al., 2015; Liu et al., 2013b; Ren et al., 2016; Singh et al., 2010). Several studies reported a 
decrease of nitrate $\left(\mathrm{NO}_{3}^{-}\right)$retention over time, indicating that the effectiveness of nutrient retention may be an artefact of fresh biochars that may not continue over a longer period of time (Beusch et al., 2019; Eykelbosh et al., 2015; Gronwald et al., 2015; Kanthle et al., 2016). However, due to increase of CEC, aged biochars may provide a higher potential to retain cations (Mia et al., 2017).

\section{Biochar as a Soil Ameliorant}

The majority of studies concentrates on the soil amending effects of biochar that benefit soil fertility (Solaiman \& Anawar, 2015; Wu et al., 2019). Table 1 gives an overview soil properties that are positively affected by biochar addition.

Table 1. Overview of chemical, physical, hydrological, and biological soil properties that are positively affected by biochar addition.

\begin{tabular}{|c|c|}
\hline & References \\
\hline \multicolumn{2}{|l|}{$\begin{array}{l}\text { Chemical } \\
\text { properties }\end{array}$} \\
\hline $\begin{array}{c}\text { Increase } \\
\text { of } \mathrm{pH}\end{array}$ & $\begin{array}{l}\text { E.g. Cheng et al. (2018); Gopal et al. (2020); Gul et al. (2015); } \\
\text { Herath et al. (2013); Hossain et al. (2020); Laird et al. (2010); Liang et al. } \\
\text { (2006); Martinsen et al. (2014); Mukherjee et al. (2011); Novak et al. (2009); } \\
\text { Palanivell et al. (2020); Silber et al. (2010); Ulyett et al. (2014); Xu et al. (2016) }\end{array}$ \\
\hline $\begin{array}{l}\text { Liming } \\
\text { effect }\end{array}$ & $\begin{array}{l}\text { E.g. Jeffery et al. (2011); Jindo et al. (2020); Liu et al. (2013a); } \\
\text { Shen et al. (2016); Sika and Hardie (2014); Verheijen et al. (2010) }\end{array}$ \\
\hline $\begin{array}{l}\text { Increase } \\
\text { of SOC }\end{array}$ & $\begin{array}{l}\text { E.g. Arthur et al. (2015); Gopal et al. (2020); Hailegnaw et al. (2019); Han et al. } \\
\text { (2016); de Jesus Duarte et al. (2019); Laird et al. (2010); Lehmann et al. (2006); } \\
\text { Liu et al. (2015); Novak et al. (2009); Prommer et al. (2014); Weng et al. (2017) }\end{array}$ \\
\hline $\begin{array}{l}\text { Increase } \\
\text { of CEC }\end{array}$ & $\begin{array}{l}\text { E.g. Gul et al. (2015); Herath et al. (2013); Jindo et al. (2020); Laird et al. } \\
\text { (2010); Liang et al. (2006); Martinsen et al. (2014); Mukherjee et al. (2011); } \\
\text { Silber et al. (2010) }\end{array}$ \\
\hline $\begin{array}{l}\text { Addition of nu- } \\
\text { trients }\end{array}$ & $\begin{array}{l}\text { E.g. Cheng et al. (2018); Gopal et al. (2020); Han et al. (2016); Hien et al. } \\
\text { (2021); Hossain et al. (2020); Ilyas et al. (2021); Jindo et al. (2020); Laird et al. } \\
\text { (2010); Martinsen et al. (2014); Novak et al. (2009); Piash et al. (2021) }\end{array}$ \\
\hline $\begin{array}{l}\text { Increase of nu- } \\
\text { trient retention }\end{array}$ & $\begin{array}{l}\text { E.g. Agegnehu et al. (2015); Beusch et al. (2019); Cheng et al. (2018); } \\
\text { Hossain et al. (2020); Lima et al. (2018); Limwikran et al. (2019); } \\
\text { Singh et al. (2010); Steiner et al. (2008); Ulyett et al. (2014) }\end{array}$ \\
\hline $\begin{array}{c}\text { Reduction of } \\
\text { nutrient leaching }\end{array}$ & $\begin{array}{l}\text { E.g. Agegnehu et al. (2015); Beusch et al. (2019); Blanco-Canqui (2021); } \\
\text { Cheng et al. (2018); Hossain et al. (2020); Kanthle et al. (2016); } \\
\text { Novak et al. (2009); Sika and Hardie (2014); Singh et al. (2010); } \\
\text { Steiner et al. (2008); Xu et al. (2016) }\end{array}$ \\
\hline \multicolumn{2}{|l|}{$\begin{array}{l}\text { Physical } \\
\text { properties }\end{array}$} \\
\hline $\begin{array}{c}\text { Reduction } \\
\text { of bulk density }\end{array}$ & $\begin{array}{l}\text { E.g. Abel et al. (2013); Basso et al. (2013); Burrell et al. (2016); Hardie et al. } \\
\text { (2014); Herath et al. (2013); Hossain et al. (2020); de Jesus Duarte et al. (2019); } \\
\text { Jiang et al. (2019); Obia et al. (2016); Omondi et al. (2016); Qian et al. (2020) }\end{array}$ \\
\hline $\begin{array}{l}\text { Enhanced } \\
\text { aggregate } \\
\text { stability }\end{array}$ & $\begin{array}{l}\text { E.g. Burrell et al. (2016); Gul et al. (2015); Han et al. (2021); } \\
\text { Herath et al. (2013); Hossain et al. (2020); Obia et al. (2016); } \\
\text { Omondi et al. (2016); Ouyang et al. (2013); Soinne et al. (2014) }\end{array}$ \\
\hline $\begin{array}{l}\text { Increase } \\
\text { of SSA }\end{array}$ & $\begin{array}{l}\text { E.g. Arthur et al. (2015); Cheng et al. (2018); Ippolito et al. (2020); } \\
\text { Laird et al. (2010); Liang et al. (2006); Lima et al. (2018) }\end{array}$ \\
\hline
\end{tabular}




\section{Continued}

\begin{tabular}{|c|c|}
\hline $\begin{array}{l}\text { Increase of } \\
\text { porosity }\end{array}$ & $\begin{array}{l}\text { E.g. Abel et al. (2013); Głab et al. (2016); Hossain et al. (2020); } \\
\text { de Jesus Duarte et al. (2019); de Melo Carvalho et al. (2014); } \\
\text { Obia et al. (2016); Omondi et al. (2016); Qian et al. (2020) }\end{array}$ \\
\hline \multicolumn{2}{|l|}{$\begin{array}{l}\text { Hydrological } \\
\text { properties }\end{array}$} \\
\hline $\begin{array}{l}\text { Increased } \\
\text { water-holding } \\
\text { capacity }\end{array}$ & $\begin{array}{l}\text { E.g. Agegnehu et al. (2015); Basso et al. (2013); Castellini et al. (2015); } \\
\text { Herath et al. (2013); Hien et al. (2021); Hossain et al. (2020); Jeffery et al. } \\
\text { (2011); Lima et al. (2018); Obia et al. (2016); Omondi et al. (2016); } \\
\text { Ouyang et al. (2013); Ulyett et al. (2014); Xu et al. (2016) }\end{array}$ \\
\hline $\begin{array}{l}\text { Increase of soil } \\
\text { water content }\end{array}$ & $\begin{array}{l}\text { E.g. Abel et al. (2013); Basso et al. (2013); Głab et al. (2016); } \\
\text { Hardie et al. (2014); Qian et al. (2020) }\end{array}$ \\
\hline $\begin{array}{l}\text { Increase of plant } \\
\text { available water }\end{array}$ & $\begin{array}{l}\text { E.g. Abel et al. (2013); Blanco-Canqui (2021); Burrell et al. (2016); } \\
\text { de Jesus Duarte et al. (2019); Martinsen et al. (2014); } \\
\text { de Melo Carvalho et al. (2014); Omondi et al. (2016); Qian et al. (2020) }\end{array}$ \\
\hline \multicolumn{2}{|l|}{$\begin{array}{l}\text { Biological } \\
\text { properties }\end{array}$} \\
\hline $\begin{array}{c}\text { Increase of } \\
\text { microbial }\end{array}$ & $\begin{array}{l}\text { E.g. Blanco-Canqui (2021); Gao et al. (2019); Gopal et al. (2020); } \\
\text { Gul et al. (2015); Gwenzi et al. (2015); Han et al. (2021); } \\
\text { Heitkötter and Marschner (2015); Hossain et al. (2020); Jaafar et al. (2015); }\end{array}$ \\
\hline $\begin{array}{l}\text { biomass, activity, } \\
\text { or diversity }\end{array}$ & $\begin{array}{l}\text { Liu et al. (2015); Madiba et al. (2016); Nelissen et al. (2014a); Prommer et al. } \\
\text { (2014); Sánchez-García et al. (2015); Xu et al. (2016); Van Zwieten et al. } \\
\text { (2010a) }\end{array}$ \\
\hline $\begin{array}{l}\text { Habitat for } \\
\text { microorganisms }\end{array}$ & $\begin{array}{l}\text { E.g. Gul et al. (2015); Kim et al. (2013); Lehmann et al. (2011); } \\
\text { Molnár et al. (2016) }\end{array}$ \\
\hline $\begin{array}{l}\text { Increase of } \\
\text { arbuscular } \\
\text { mycorrhizal } \\
\text { colonisation }\end{array}$ & $\begin{array}{l}\text { E.g. Blackwell et al. (2010); Gopal et al. (2020); LeCroy et al. (2013); } \\
\text { Lehmann et al. (2011); Madiba et al. (2016); Shen et al. (2016); } \\
\text { Solaiman et al. (2010); Warnock et al. (2007) }\end{array}$ \\
\hline $\begin{array}{l}\text { Increase of } \\
\text { earthworm } \\
\text { abundance } \\
\text { and activity }\end{array}$ & E.g. Kamau et al. (2019); Topoliantz et al. (2005); Van Zwieten et al. (2010b) \\
\hline
\end{tabular}

Biochar application to soils can also mitigate climate change by sequestration of carbon (e.g. Lehmann et al., 2006; Lorenz \& Lal, 2014; Mao et al., 2012; Wang et al., 2016) and reduce greenhouse gas (GHG) emissions (e.g. Gurwick et al., 2013; Mukherjee \& Lal, 2013; Nelissen et al., 2014b; Singh et al., 2010; Woolf et al., 2010). Biochar can also be a management option for degraded soils and support immobilisation of heavy metals (e.g. Beesley et al., 2011; Schweiker et al., 2014; Uchimiya et al., 2010; Wagner and Kaupenjohann, 2014), remediate organic contaminants (e.g. Ahmad et al., 2014; Beesley et al., 2011; Chen et al., 2008; Hale et al., 2016), mitigate salt stress to plants in saline soils (e.g. Lashari et al., 2013; Saifullah et al., 2018; dos Santos et al., 2021; Sun et al., 2017; Thomas et al., 2013), and improve soil nutrient availability in acidic soils (e.g. Bornø et al., 2018; Hass et al., 2012; Hong \& Lu, 2018; Molnár et al., 2016; Novak et al., 2009; Xu et al., 2014). Besides improving crop yields (e.g. Agegnehu et al., 2015; Blan- 
co-Canqui, 2021; Gopal et al., 2020; Jeffery et al., 2011; Kamau et al., 2019; Liu et al., 2013a; Martinsen et al., 2014; dos Santos et al., 2021; Spokas et al., 2012; Zhang et al., 2015), biochar can offer further benefits to agriculture, for example promoting livestock health and growth by addition of biochar to animal feed (e.g. Boonanuntanasarn et al., 2014; Chen et al., 2019; Han et al., 2014; Villalba et al., 2002; Watarai \& Tana, 2005).

Biochar is also applied to remove organic and inorganic contaminants from water, in particular excess of nutrients in wastewater (e.g. Ahmad et al., 2014; Durn et al., 2016; Ghezzehei et al., 2014; Li et al., 2019). Biochar can also add value to unused biomass wastes by nutrient recycling (e.g. Krause et al., 2015; Moreira et al., 2017; Roberts et al., 2010; You \& Wang, 2019) and the production of biofuel and bioenergy (e.g. Bartoli et al., 2020; Chen et al., 2019; Jeffery et al., 2015; Krause et al., 2015; Liao et al., 2013).

\section{Conclusions and Outlook}

Biochar has the potential to meliorate soils, increase their long-term fertility, and hence contribute to food safety within a region. By the use of currently unused residues, biochar can also contribute to close nutrient cycles and sequester carbon in soils. The numerous types of biochars exhibit a broad range of properties, mainly controlled by feedstock and pyrolysis temperature. When incorporated into the soil, biochar characteristics change over time. Even though numerous studies have been conducted with a myriad of biochars of all kinds and properties, the majority of studies focused on short-time effects. Still, there is a lack of field experiments, in particular over longer time scales of more than just one or two years. This would generate knowledge about the prolonged effects of biochar addition on soil properties that is crucial to upscale biochar application at farm level. In the future, a more systematic testing of biochar effects in the long-term and on larger scales involving different soil types and crops is needed to help bring the benefits of biochar into practice.

\section{Acknowledgements}

The author wants to thank Martin Beusch and Julie Elbert for proofreading the manuscript, and her co-workers at The Writing Academic for their empowering community and support, in particular Ksenia Meshkova for her continuous encouragement. The author also thanks the anonymous reviewers for their valuable suggestions that helped improving the manuscript.

\section{Conflicts of Interest}

The author declares no conflicts of interest regarding the publication of this paper.

\section{References}

Abel, S., Peters, A., Trinks, S., Schonsky, H., Facklam, M., \& Wessolek, G. (2013). Impact 
of Biochar and Hydrochar Addition on Water Retention and Water Repellency of Sandy Soil. Geoderma, 202-203, 183-191. https://doi.org/10.1016/j.geoderma.2013.03.003

Agegnehu, G., Bird, M. I., Nelson, P. N., \& Bass, A. M. (2015). The Ameliorating Effects of Biochar and Compost on Soil Quality and Plant Growth on a Ferralsol. Soil Research, 53, 1-12. https://doi.org/10.1071/SR14118

Ahmad, M., Rajapaksha, A. U., Lim, J. E., Zhang, M., Bolan, N., Mohan, D., Vithanage, M., Lee, S. S., \& Ok, Y. S. (2014). Biochar as a Sorbent for Contaminant Management in Soil and Water: A Review. Chemosphere, 99, 19-33. https://doi.org/10.1016/j.chemosphere.2013.10.071

Al-Wabel, M. I., Al-Omran, A., El-Naggar, A. H., Nadeem, M., \& Usman, A. R. (2013). Pyrolysis Temperature Induced Changes in Characteristics and Chemical Composition of Biochar Produced from Conocarpus Wastes. Bioresource Technology, 131, 374-379. https://doi.org/10.1016/j.biortech.2012.12.165

Arthur, E., Tuller, M., Moldrup, P., \& de Jonge, L. (2015). Effects of Biochar and Manure Amendments on Water Vapor Sorption in a Sandy Loam Soil. Geoderma, 243-244, 175-182. https://doi.org/10.1016/j.geoderma.2015.01.001

Bartoli, M., Giorcelli, M., Jagdale, P., Rovere, M., \& Tagliaferro, A. (2020). A Review of Non-Soil Biochar Applications. Materials, 13, Article No. 261. https://doi.org/10.3390/ma13020261

Basso, A. S., Miguez, F. E., Laird, D. A., Horton, R., \& Westgate, M. (2013). Assessing Potential of Biochar for Increasing Water-Holding Capacity of Sandy Soils. GCB Bioenergy, 5, 132-143. https://doi.org/10.1111/gcbb.12026

Beesley, L., Moreno-Jiménez, E., Gomez-Eyles, J. L., Harris, E., Robinson, B., \& Sizmur, T. (2011). A Review of Biochars' Potential Role in the Remediation, Revegetation and Restoration of Contaminated Soils. Environmental Pollution, 159, 3269-3282.

https://doi.org/10.1016/j.envpol.2011.07.023

Beusch, C., Cierjacks, A., Böhm, J., Mertens, J., Bischoff, W.-A., de Araújo Filho, J. C., \& Kaupenjohann, M. (2019). Biochar vs. Clay: Comparison of Their Effects on Nutrient Retention of a Tropical Arenosol. Geoderma, 337, 524-535. https://doi.org/10.1016/j.geoderma.2018.09.043

Blackwell, P., Krull, E., Butler, G., Herbert, A., \& Solaiman, Z. (2010). Effect of Banded Biochar on Dryland Wheat Production and Fertiliser Use in South-Western Australia: an Agronomic and Economic Perspective. Australian Journal of Soil Research, 48, 531-545. https://doi.org/10.1071/SR10014

Blanco-Canqui, H. (2021). Does Biochar Improve All Soil Ecosystem Services? GCB Bioenergy, 13, 291-304. https://doi.org/10.1111/gcbb.12783

Boonanuntanasarn, S., Khaomek, P., Pitaksong, T., \& Hua, Y. (2014). The Effects of the Supplementation of Activated Charcoal on the Growth, Health Status and Fillet Composition-Odor of Nile Tilapia (Oreochromis niloticus) before Harvesting. Aquaculture International, 22, 1417-1436. https://doi.org/10.1007/s10499-014-9756-8

Bornø, M. L., Müller-Stöver, D. S., \& Liu, F. (2018). Contrasting Effects of Biochar on Phosphorus Dynamics and Bioavailability in Different Soil Types. Science of the Total Environment, 627, 963-974. https://doi.org/10.1016/j.scitotenv.2018.01.283

Burrell, L. D., Zehetner, F., Rampazzo, N., Wimmer, B., \& Soja, G. (2016). Long-Term Effects of Biochar on Soil Physical Properties. Geoderma, 282, 96-102. https://doi.org/10.1016/j.geoderma.2016.07.019

Castellini, M., Giglio, L., Niedda, M., Palumbo, A., \& Ventrella, D. (2015). Impact of Bio- 
char Addition on the Physical and Hydraulic Properties of a Clay Soil. Soil and Tillage Research, 154, 1-13. https://doi.org/10.1016/j.still.2015.06.016

Chen, B., Zhou, D., \& Zhu, L. (2008). Transitional Adsorption and Partition of Nonpolar and Polar Aromatic Contaminants by Biochars of Pine Needles with Different Pyrolytic Temperatures. Environmental Science \& Technology, 42, 5137-5143. https://doi.org/10.1021/es8002684

Chen, W., Meng, J., Han, X., Lan, Y., \& Zhang, W. (2019). Past, Present, and Future of Biochar. Biochar, 1, 75-87. https://doi.org/10.1007/s42773-019-00008-3

Cheng, C., \& Lehmann, J. (2009). Ageing of Black Carbon along a Temperature Gradient. Chemosphere, 75, 1021-1027. https://doi.org/10.1016/j.chemosphere.2009.01.045

Cheng, C., Lehmann, J., \& Engelhard, M. H. (2008). Natural Oxidation of Black Carbon in Soils: Changes in Molecular form and Surface Charge along a Climosequence. Geochimica et Cosmochimica Acta, 72, 1598-1610.

https://doi.org/10.1016/j.gca.2008.01.010

Cheng, H., Jones, D. L., Hill, P., Bastami, M. S., \& Tu, C. L. (2018). Influence of Biochar Produced from Different Pyrolysis Temperature on Nutrient Retention and Leaching. Archives of Agronomy and Soil Science, 64, 850-859. https://doi.org/10.1080/03650340.2017.1384545

Chun, Y., Sheng, G., Chiou, C. T., \& Xing, B. (2004). Compositions and Sorptive properties of Crop Residue-Derived Chars. Environmental Science \& Technology, 38, 4649-4655. https://doi.org/10.1021/es035034w

Das, S. K., Ghosh, G. K., Avasthe, R. K., \& Sinha, K. (2021). Compositional Heterogeneity of Different Biochar: Effect of Pyrolysis Temperature and Feed Stocks. Journal of Environmental Management, 278, Article ID: 111501.

https://doi.org/10.1016/j.jenvman.2020.111501

de Jesus Duarte, S., Glaser, B., Paiva de Lima, R., \& Pelegrino Cerri, E. C. (2019). Chemical, Physical, and Hydraulic Properties as Affected by One Year of Miscanthus Biochar Interaction with Sandy and Loamy Tropical Soils. Soil Systems, 3, Article No. 24. https://doi.org/10.3390/soilsystems3020024

de la Rosa, J. M., Rosado, M., Paneque, M., Miller, A. Z., \& Knicker, H. (2018). Effects of Aging under Field Conditions on Biochar Structure and Composition: Implications for Biochar Stability in Soils. Science of the Total Environment, 613-614, 969-976. https://doi.org/10.1016/j.scitotenv.2017.09.124

de Melo Carvalho, M. T., de Holanda Nunes Maia, A., Madari, B. E., Bastiaans, L., van Oort, P. A. J., Heinemann, A. B., Soler da Silva, M. A., Petter, F. A., Marimon Jr., B. H., \& Meinke, H. (2014). Biochar Increases Plant-Available Water in a Sandy Loam Soil under an Aerobic Rice Crop System. Solid Earth, 5, 939-952.

https://doi.org/10.5194/se-5-939-2014

dos Santos, W. M., Gonzaga, M. I. S., da Silva, J. A., de Almeida, A. Q., de Jesus Santos, J. C., Gonzaga, T. A. S., da Silva Lima, I., \& Araújo, E. M. (2021). Effectiveness of Different Biochars in Remediating a Salt-Affected Luvisol in Northeast Brazil. Biochar, 3, 149-159. https://doi.org/10.1007/s42773-020-00084-w

Downie, A., Crosky, A., \& Munroe, P. (2009). Physical Properties of Biochar. In J. Lehmann, \& S. Joseph (Eds.), Biochar for Environmental Management: Science and Technology (pp. 13-29). Earthscan.

Durn, G., Hrenovic, J., \& Sekovanic, L. (2016). Terra Rossa as the Substrate for Biological Phosphate Removal from Wastewater. Clay Minerals, 48, 725-738. https://doi.org/10.1180/claymin.2013.048.5.05

Eykelbosh, A. J., Johnson, M. S., \& Couto, E. G. (2015). Biochar Decreases Dissolved Or- 
ganic Carbon but Not Nitrate Leaching in Relation to Vinasse Application in a Brazilian Sugarcane Soil. Journal of Environmental Management, 149, 9-16.

https://doi.org/10.1016/j.jenvman.2014.09.033

Ezepue, G. C., Uzoh, I., \& Unagwu, B. (2019). Biochar-Induced Modification of Soil Properties and the Effect on Crop Production. Advances in Agricultural Science, 7, 59-87.

Fawzy, S., Osman, A. I., Yang, H., Doran, J., \& Rooney, D. W. (2021). Industrial Biochar Systems for Atmospheric Carbon Removal: A Review. Environmental Chemistry Letters, 19, 3023-3055. https://doi.org/10.1007/s10311-021-01210-1

Gao, S., DeLuca, T. H., \& Cleveland, C. C. (2019). Biochar Additions Alter Phosphorus and Nitrogen Availability in Agricultural Ecosystems: A Meta-Analysis. Science of the Total Environment, 654, 463-472. https://doi.org/10.1016/j.scitotenv.2018.11.124

Ghaffar, A., Ghosh, S., Li, F., Dong, X., Zhang, D., Wu, M., Li, H., \& Pan, B. (2015). Effect of Biochar Aging on Surface Characteristics and Adsorption Behavior of Dialkyl Phthalates. Environmental Pollution, 206, 502-509.

https://doi.org/10.1016/j.envpol.2015.08.001

Ghezzehei, T. A., Sarkhot, D. V., \& Berhe, A. A. (2014). Biochar Can Be Used to Capture Essential Nutrients from Dairy Wastewater and Improve Soil Physic-Chemical Properties. Solid Earth, 5, 953-962. https://doi.org/10.5194/se-5-953-2014

Głab, T., Palmowska, J., Zaleski, T., \& Gondek, K. (2016). Effect of Biochar Application on Soil Hydrological Properties and Physical Quality of Sandy Soil. Geoderma, 281, 11-20.

https://doi.org/10.1016/j.geoderma.2016.06.028

Glaser, B., \& Birk, J. J. (2012). State of the Scientific Knowledge on Properties and Genesis of Anthropogenic Dark Earths in Central Amazonia (Terra Preta de Índio). Geochimicaet Cosmochimica Acta, 82, 39-51. https://doi.org/10.1016/j.gca.2010.11.029

Glaser, B., Haumaier, L., Guggenberger, G., \& Zech, W. (2001). The 'Terra Preta' Phenomenon: A Model for Sustainable Agriculture in the Humid Tropics. Naturwissenschaften, 88, 37-41. https://doi.org/10.1007/s001140000193

Gopal, M., Gupta, A., Shahul Hameed, K., Sathyaseelan, N., Khadeejath Rajeela, T. H., \& Thomas, G. V. (2020). Biochars Produced from Coconut Palm Biomass Residues Can Aid Regenerative Agriculture by Improving Soil Properties and Plant Yield in Humid Tropics. Biochar, 2, 211-226. https://doi.org/10.1007/s42773-020-00043-5

Gronwald, M., Don, A., Tiemeyer, B., \& Helfrich, M. (2015). Effects of Fresh and Aged Chars from Pyrolysis and Hydrothermal Carbonization on Nutrient Sorption in Agricultural Soils. SOIL, 1, 475-489. https://doi.org/10.5194/soil-1-475-2015

Gul, S., Whalen, J. K., Thomas, B. W., Sachdeva, V., \& Deng, H. (2015). Physico-Chemical Properties and Microbial Responses in Biochar-Amended Soils: Mechanisms and Future Directions. Agriculture, Ecosystems \& Environment, 206, 46-59. https://doi.org/10.1016/j.agee.2015.03.015

Gurwick, N. P., Moore, L. A., Kelly, C., \& Elias, P. (2013). A Systematic Review of Biochar Research, with a Focus on Its Stability in Situ and Its Promise as a Climate Mitigation Strategy. PLoS ONE, 8, e75932. https://doi.org/10.1371/journal.pone.0075932

Gwenzi, W., Chaukura, N., Mukome, F. N., Machado, S., \& Nyamasoka, B. (2015). Biochar Production and Applications in Sub-Saharan Africa: Opportunities, Constraints, Risks and Uncertainties. Journal of Environmental Management, 150, 250-261. https://doi.org/10.1016/j.jenvman.2014.11.027

Hailegnaw, N. S., Mercl, F., Pracke, K., Száková, J., \& Tlustoš, P. (2019). High Temperature-Produced Biochar Can Be Efficient in Nitrate Loss Prevention and Carbon Se- 
questration. Geoderma, 338, 48-55. https://doi.org/10.1016/j.geoderma.2018.11.006

Hale, S. E., Arp, H. P. H., Kupryianchyk, D., \& Cornelissen, G. (2016). A Synthesis of Parameters Related to the Binding of Neutral Organic Compounds to Charcoal. Chemosphere, 144, 65-74. https://doi.org/10.1016/j.chemosphere.2015.08.047

Han, F., Ren, L., \& Zhang, X.-C. (2016). Effect of Biochar on the Soil Nutrients about Different Grasslands in the Loess Plateau. Catena, 137, 554-562. https://doi.org/10.1016/j.catena.2015.11.002

Han, J., Zhang, F., Du, L., Han, X., Chen, W., \& Meng, J. (2014). Effects of Dietary Biochar Including Vinegar Liquid on Growth Performance, Nutrient Digestibility, Blood Characteristics and Fecal Noxious Gas Emission in Weaned Piglets. Journal of Animal and Veterinary Advances, 13, 1072-1079. https://doi.org/10.36478/javaa.2014.1072.1079

Han, L., Zhang, B., Chen, L., Feng, Y., Yang, Y., \& Sun, K. (2021). Impact of Biochar Amendment on Soil Aggregation Varied with Incubation Duration and Biochar Pyrolysis Temperature. Biochar, 3, 339-347. https://doi.org/10.1007/s42773-021-00097-z

Hardie, M., Clothier, B., Bound, S., Oliver, G., \& Close, D. (2014). Does Biochar Influence Soil Physical Properties and Soil Water Availability? Plant and Soil, 376, 347-361. https://doi.org/10.1007/s11104-013-1980-x

Hass, A., Gonzalez, J. M., Lima, I. M., Godwin, H. W., Halvorson, J. J., \& Boyer, D. G. (2012). Chicken Manure Biochar as Liming and Nutrient Source for Acid Appalachian Soil. Journal of Environmental Quality, 41, 1096-1106. https://doi.org/10.2134/jeq2011.0124

Heitkötter, J., \& Marschner, B. (2015). Interactive Effects of Biochar Ageing in Soils Related to Feedstock, Pyrolysis Temperature, and Historic Charcoal Production. Geoderma, 245-246, 56-64. https://doi.org/10.1016/j.geoderma.2015.01.012

Herath, H., Camps-Arbestain, M., \& Hedley, M. (2013). Effect of Biochar on Soil Physical Properties in Two Contrasting Soils: An Alfisol and an Andisol. Geoderma, 209-210, 188-197. https://doi.org/10.1016/j.geoderma.2013.06.016

Hien, T. T. T., Tsubota, T., Taniguchi, T., \& Shinogi, Y. (2021). Enhancing Soilwater Holding Capacity and Provision of a Potassium Source via Optimization of the Pyrolysis of Bamboo Biochar. Biochar, 3, 51-61. https://doi.org/10.1007/s42773-020-00071-1

Hong, C., \& Lu, S. (2018). Does Biochar Affect the Availability and Chemical Fractionation of Phosphate in Soils? Environmental Science and Pollution Research, 25, 8725-8734. https://doi.org/10.1007/s11356-018-1219-8

Hossain, M. Z., Bahar, M. M., Sarkar, B., Donne, S. W., Ok, Y. S., Palansooriya, K. N., Kirkham, M. B., Chowdhury, S., \& Bolan, N. (2020). Biochar and Its Importance on Nutrient Dynamics in Soil and Plant. Biochar, 2, 379-420. https://doi.org/10.1007/s42773-020-00065-z

Ilyas, M., Arif, M., Akhtar, K., Riaz, M., \& Wang, H. (2021). Diverse Feedstock's Biochars as Supplementary K Fertilizer Improves Maize Productivity, Soil Organic C and KUE under Semiarid Climate. Soil and Tillage Research, 211, Article ID: 105015. https://doi.org/10.1016/j.still.2021.105015

Ippolito, J. A., Cui, L., Kammann, C., Wrage-Mönnig, N., Estavillo, J. M., Fuertes-Mendizabal, T., Cayuela, M. L., Sigua, G., Novak, J., Spokas, K., \& Borchard, N. (2020). Feedstock Choice, Pyrolysis Temperature and Type Influence Biochar Characteristics: A Comprehensive Meta-Data Analysis Review. Biochar, 2, 421-438. https://doi.org/10.1007/s42773-020-00067-x

Jaafar, N. M., Clode, P. L., \& Abbott, L. K. (2015). Biochar-Soil Interactions in Four Agricultural Soils. Pedosphere, 25, 729-736. 
https://doi.org/10.1016/S1002-0160(15)30054-0

Jeffery, S., Bezemer, T. M., Cornelissen, G., Kuyper, T. W., Lehmann, J., Mommer, L., Sohi, S. P., van de Voorde, T. F., Wardle, D. A., \& van Groenigen, J.W. (2015). The Way Forward in Biochar Research: Targeting Trade-Offs between the Potential Wins. GCB Bioenergy, 7, 1-13. https://doi.org/10.1111/gcbb.12132

Jeffery, S., Verheijen, F., van der Velde, M., \& Bastos, A. (2011). A Quantitative Review of the Effects of Biochar Application to Soils on Crop Productivity Using Meta-Analysis. Agriculture, Ecosystems \& Environment, 144, 175-187. https://doi.org/10.1016/j.agee.2011.08.015

Jiang, X., Tan, X., Cheng, J., Haddix, M. L., \& Cotrufo, M. F. (2019). Interactions between Aged Biochar, Fresh Low Molecular Weight Carbon and Soil Organic Carbon after 3.5 Years Soil-Biochar Incubations. Geoderma, 333, 99-107. https://doi.org/10.1016/j.geoderma.2018.07.016

Jindo, K., Audette, Y., Higashikawa, F. S., Silva, C. A., Akashi, K., Mastrolonardo, G., Sánchez-Monedero, M. A., \& Mondini, C. (2020). Role of Biochar in Promoting Circular Economy in the Agriculture Sector. Part 1: A Review of the Biochar Roles in Soil N, $\mathrm{P}$ and K Cycles. Chemical and Biological Technologies in Agriculture, 7, Article No. 15. https://doi.org/10.1186/s40538-020-00182-8

Joseph, S., Camps-Arbestain, M., Lin, Y., Munroe, P., Chia, C., Hook, J., Van Zwieten, L., Kimber, S., Cowie, A., Singh, B., Lehmann, J., Foidl, N., Smernik, R., \& Amonette, J. (2010). An Investigation into the Reactions of Biochar in Soil. Australian Journal of Soil Research, 48, 501-515. https://doi.org/10.1071/SR10009

Kamau, S., Karanja, N. K., Ayuke, F. O., \& Lehmann, J. (2019). Short-Term Influence of Biochar and Fertilizer-Biochar Blends on Soil Nutrients, Fauna and Maize Growth. Biology and Fertility of Soils, 55, 661-673. https://doi.org/10.1007/s00374-019-01381-8

Kanthle, A. K., Lenka, N. K., Lenka, S., \& Tediar, K. (2016). Biochar Impact on Nitrate Leaching as Influenced by Native Soil Organic Carbon in an Inceptisol of Central India. Soil and Tillage Research, 157, 65-72. https://doi.org/10.1016/j.still.2015.11.009

Kim, P., Johnson, A. M., Essington, M. E., Radosevich, M., Kwon, W.-T., Lee, S.-H., Rials, T. G., \& Labbé, N. (2013). Effect of pH on Surface Characteristics of Switch Grass-Derived Biochars Produced by Fast Pyrolysis. Chemosphere, 90, 2623-2630.

https://doi.org/10.1016/j.chemosphere.2012.11.021

Knowles, O. A., Robinson, B. H., Contangelo, A., \& Clucas, L. (2011). Biochar for the Mitigation of Nitrate Leaching from Soil Amended with Biosolids. Science of the Total Environment, 409, 3206-3210. https://doi.org/10.1016/j.scitotenv.2011.05.011

Krause, A., Kaupenjohann, M., George, E., \& Koeppel, J. (2015). Nutrient Recycling from Sanitation and Energy Systems to the Agroecosystem-Ecological Research on Case Studies in Karagwe, Tanzania. African Journal of Agricultural Research, 10, 4039-4052. https://doi.org/10.5897/AJAR2015.10102

Laird, D. A., Fleming, P., Davis, D. D., Horton, R., Wang, B., \& Karlen, D. L. (2010). Impact of Biochar Amendments on the Quality of a Typical Midwestern Agricultural Soil. Geoderma, 158, 443-449. https://doi.org/10.1016/j.geoderma.2010.05.013

Lashari, M. S., Liu, Y., Li, L., Pan, W., Fu, J., Pan, G., Zheng, J., Zheng, J., Zhang, X., \& Yu, X. (2013). Effects of Amendment of Biochar-Manure Compost in Conjunction with Pyroligneous Solution on Soil Quality and Wheat Yield of a Salt-Stressed Cropland from Central China Great Plain. Field Crops Research, 144, 113-118. https://doi.org/10.1016/j.fcr.2012.11.015

Lawrinenko, M., Laird, D. A., Johnson, R. L., \& Jing, D. (2016). Accelerated Aging of Biochars: Impact on Anion Exchange Capacity. Carbon, 103, 217-227. 
https://doi.org/10.1016/j.carbon.2016.02.096

LeCroy, C., Masiello, C. A., Rudgers, J. A., Hockaday, W. C., \& Silberg, J. J. (2013). Nitrogen, Biochar, and Mycorrhizae: Alteration of the Symbiosis and Oxidation of the Char Surface. Soil Biology and Biochemistry, 58, 248-254. https://doi.org/10.1016/j.soilbio.2012.11.023

Lehmann, J., \& Joseph, S. (2015). Biochar for Environmental Management: Science, Technology and Implementation (2nd ed.). Routledge. https://doi.org/10.4324/9780203762264

Lehmann, J., da Silva Jr., J., Steiner, C., Nehls, T., Zech, W., \& Glaser, B. (2003). Nutrient Availability and Leaching in an Archaeological Anthrosol and a Ferralsol of the Central Amazon Basin: fertilizer, Manure and charcoal amendments. Plant and Soil, 249, 343-357. https://doi.org/10.1023/A:1022833116184

Lehmann, J., Gaunt, J., \& Rondon, M. (2006). Biochar Sequestration in Terrestrial Ecosystems-A Review. Mitigation and Adaptation Strategies for Global Change, 11, 403-427. https://doi.org/10.1007/s11027-005-9006-5

Lehmann, J., Kuzyakov, Y., Pan, G., \& Ok, Y. (2015). Biochars and the plant-soil interface. Plant and Soil, 395, 1-5. https://doi.org/10.1007/s11104-015-2658-3

Lehmann, J., Rillig, M. C., Thies, J., Masiello, C. A., Hockaday, W. C., \& Crowley, D. (2011). Biochar Effects on Soil Biota-A Review. Soil Biology and Biochemistry, 43, 1812-1836. https://doi.org/10.1016/j.soilbio.2011.04.022

Li, X., Zhao, C., \& Zhang, M. (2019). Biochar for anionic contaminants removal from water. In Y. S. Ok, D. C. Tsang, N. Bolan, \& J. Novak (Eds.), Biochar from Biomass and Waste (pp. 143-160). Elsevier. https://doi.org/10.1016/B978-0-12-811729-3.00008-X

Li, Y., Xing, B., Ding, Y., Han, X., \& Wang, S. (2020). A Critical Review of the Production and Advanced Utilization of Biochar via Selective Pyrolysis of Lignocellulosic Biomass. Bioresource Technology, 312, Article ID: 123614. https://doi.org/10.1016/j.biortech.2020.123614

Liang, B., Lehmann, J., Solomon, D., Kinyangi, J., Grossman, J., O’Neill, B., Skjemstad, J. O., Thies, J., Luizao, F. J., Petersen, J., \& Neves, E. G. (2006). Black Carbon Increases Cation Exchange Capacity in Soils. Soil Science Society of America Journal, 70, 1719-1730. https://doi.org/10.2136/sssaj2005.0383

Liao, R., Gao, B., \& Fang, J. (2013). Invasive Plants as Feedstock for Biochar and Bioenergy Production. Bioresource Technology, 140, 439-442.

https://doi.org/10.1016/j.biortech.2013.04.117

Lima, J. R. d. S., de Moraes Silva, W., de Medeiros, E. V., Duda, G. P., Corrêa, M. M., Martins Filho, A. P., Clermont-Dauphin, C., Antonino, A. C. D., \& Hammecker, C. (2018). Effect of Biochar on Physicochemical Properties of a Sandy Soil and Maize Growth in a Greenhouse Experiment. Geoderma, 319, 14-23.

https://doi.org/10.1016/j.geoderma.2017.12.033

Limwikran, T., Kheoruenromne, I., Suddhiprakarn, A., Prakongkep, N., \& Gilkes, R. J. (2019). Most Plant Nutrient Elements Are Retained by Biochar in Soil. Soil Systems, 3, Article No. 75. https://doi.org/10.3390/soilsystems3040075

Liu, S., Zhang, Y., Zong, Y., Hu, Z., Wu, S., Zhou, J., Jin, Y., \& Zou, J. (2015). Response of Soil Carbon Dioxide Fluxes, Soil Organic Carbon and Microbial Biomass Carbon to Biochar Amendment: A Meta-Analysis. GCB Bioenergy, 8, 392-406.

https://doi.org/10.1111/gcbb.12265

Liu, X., Zhang, A., Ji, C., Joseph, S., Bian, R., Li, L., Pan, G., \& Paz-Ferreiro, J. (2013a). Biochar's Effect on Crop Productivity and the Dependence on Experimental Condi- 
tions-A Meta-Analysis of Literature Data. Plant and Soil, 373, 583-594. https://doi.org/10.1007/s11104-013-1806-x

Liu, Z., Demisie, W., \& Zhang, M. (2013b). Simulated Degradation of Biochar and Its Potential Environmental Implications. Environmental Pollution, 179, 146-152. https://doi.org/10.1016/j.envpol.2013.04.030

Lorenz, K., \& Lal, R. (2014). Biochar Application to Soil for Climate Change Mitigation by Soil Organic Carbon Sequestration. Journal of Plant Nutrition and Soil Science, 177, 651-670. https://doi.org/10.1002/jpln.201400058

Madiba, O. F., Solaiman, Z. M., Carson, J. K., \& Murphy, D. V. (2016). Biochar Increases Availability and Uptake of Phosphorus to Wheat under Leaching Conditions. Biology and Fertility of Soils, 52, 439-446. https://doi.org/10.1007/s00374-016-1099-3

Mao, J.-D., Johnson, R. L., Lehmann, J., Olk, D. C., Neves, E. G., Thompson, M. L., \& Schmidt-Rohr, K. (2012). Abundant and Stable Char Residues in Soils: Implications for Soil Fertility and Carbon Sequestration. Environmental Science \& Technology, 46, 9571-9576. https://doi.org/10.1021/es301107c

Martinsen, V., Mulder, J., Shitumbanuma, V., Sparrevik, M., Børresen, T., \& Cornelissen, G. (2014). Farmer-Led Maize Biochar Trials: Effect on Crop Yield and Soil Nutrients under Conservation Farming. Journal of Plant Nutrition and Soil Science, 177, 681-695. https://doi.org/10.1002/jpln.201300590

Mia, S., Dijkstra, F., \& Singh, B. (2017). Long-Term Aging of Biochar: A Molecular Understanding with Agricultural and Environmental Implications. In D. L. Sparks (Ed.), Advances in Agronomy (Vol. 141, pp. 1-51). Academic Press.

https://doi.org/10.1016/bs.agron.2016.10.001

Molnár, M., Vaszita, E., Farkas, E., Ujaczki, E., Fekete-Kertész, I., Tolner, M., Klebercz, O., Kirchkeszner, C., Gruiz, K., Uzinger, N., \& Feigl, V. (2016). Acidic Sandy Soil Improvement with Biochar-A Microcosm Study. Science of the Total Environment, 563-564, 855-865. https://doi.org/10.1016/j.scitotenv.2016.01.091

Moreira, M., Noya, I., \& Feijoo, G. (2017). The Prospective Use of Biochar as Adsorption Matrix-A Review from a Lifecycle Perspective. Bioresource Technology, 246, 135-141. https://doi.org/10.1016/j.biortech.2017.08.041

Mukherjee, A., \& Lal, R. (2013). Biochar Impacts on Soil Physical Properties and Greenhouse Gas Emissions. Agronomy, 3, 313-339.

https://doi.org/10.3390/agronomy3020313

Mukherjee, A., Zimmerman, A. R., Hamdan, R., \& Cooper, W. T. (2014). Physicochemical Changes in Pyrogenic Organic Matter (Biochar) after 15 Months of Field Aging. Solid Earth, 5, 693-704. https://doi.org/10.1111/gcbb.12156

Mukherjee, A., Zimmerman, A., \& Harris, W. (2011). Surface Chemistry Variations among a Series of Laboratory-Produced Biochars. Geoderma, 163, 247-255.

https://doi.org/10.1016/j.geoderma.2011.04.021

Nelissen, V., Rütting, T., Huygens, D., Ruysschaert, G., \& Boeckx, P. (2014a). Temporal Evolution of Biochar's Impact on Soil Nitrogen Processes-A ${ }^{15} \mathrm{~N}$ Tracing Study. $G C B$ Bioenergy, 7, 635-645. https://doi.org/10.1111/gcbb.12156

Nelissen, V., Saha, B. K., Ruysschaert, G., \& Boeckx, P. (2014b). Effect of Different Biochar and Fertilizer Types on $\mathrm{N}_{2} \mathrm{O}$ and NO Emissions. Soil Biology and Biochemistry, 70, 244-255. https://doi.org/10.1016/j.soilbio.2013.12.026

Neves, E. G., Petersen, J. B., Bartone, R. N., \& Heckenberger, M. J. (2004). The Timing of Terra Preta Formation in the Central Amazon: Archaeological Data from Three Sites. In B. Glaser, \& W. I. Woods (Eds.), Amazonian Dark Earths: Explorations in Space and Time (pp. 125-134). Springer. https://doi.org/10.1007/978-3-662-05683-7_9 
Novak, J. M., Busscher, W. J., Laird, D. L., Ahmedna, M., Watts, D. W., \& Niandou, M. A. S. (2009). Impact of Biochar Amendment on Fertility of a Southeastern Coastal Plain Soil. Soil Science, 174, 105-112. https://doi.org/10.1097/SS.0b013e3181981d9a

Obia, A., Mulder, J., Martinsen, V., Cornelissen, G., \& Børresen, T. (2016). In Situ Effects of Biochar on Aggregation, Water Retention and Porosity in Light Textured Tropical Soils. Soil and Tillage Research, 155, 35-44. https://doi.org/10.1016/j.still.2015.08.002

Omondi, M. O., Xia, X., Nahayo, A., Liu, X., Korai, P. K., \& Pan, G. (2016). Quantification of Biochar Effects on Soil Hydrological Properties Using Meta-Analysis of Literature Data. Geoderma, 274, 28-34. https://doi.org/10.1016/j.geoderma.2016.03.029

Ouyang, L., Wang, F., Tang, J., Yu, L., \& Zhang, R. (2013). Effects of Biochar Amendment on Soil Aggregates and Hydraulic Properties. Journal of Soil Science and Plant Nutrition, 13, 991-1002. https://doi.org/10.4067/S0718-95162013005000078

Palanivell, P., Ahmed, H. O., Latifah, O., \& Abdul Majid, M. N. (2020). Adsorption and Desorption of Nitrogen, Phosphorus, Potassium, and Soil Buffering Capacity Following Application of Chicken Litter Biochar to an Acid Soil. Applied Sciences, 10, Article No. 295. https://doi.org/10.3390/app10010295

Piash, M. I., Iwabuchi, K., Itoh, T., \& Uemura, K. (2021). Release of Essential Plant Nutrients from Manure- and Wood-Based Biochars. Geoderma, 397, Article ID: 115100. https://doi.org/10.1016/j.geoderma.2021.115100

Pignatello, J. J., Kwon, S., \& Lu, Y. (2006). Effect of Natural Organic Substances on the Surface and Adsorptive Properties of Environmental Black Carbon (Char): Attenuation of Surface Acitivity by Humic and Fulvic Acids. Environmental Science \& Technology, 40, 7757-7763. https://doi.org/10.1021/es061307m

Prommer, J., Wanek, W., Hofhansl, F., Trojan, D., Offre, P., Urich, T., Schleper, C., Sassmann, S., Kitzler, B., Soja, G., \& Hood-Nowotny, R. C. (2014). Biochar Decelerates Soil Organic Nitrogen Cycling but Stimulates Soil Nitrification in a Temperate Arable Field Trial. PLOS ONE, 9, e86388. https://doi.org/10.1371/journal.pone.0086388

Qian, Z., Tang, L., Zhuang, S., Zou, Y., Fu, D., \& Chen, X. (2020). Effects of Biochar Amendments on Soil Water Retention Characteristics of Red Soil at South China. Biochar, 2, 479-488. https://doi.org/10.1007/s42773-020-00068-w

Rechberger, M. V., Kloss, S., Rennhofer, H., Tintner, J., Watzinger, A., Soja, G., Lichtenegger, H., \& Zehetner, F. (2017). Changes in Biochar Physical and Chemical Properties: Accelerated Biochar Aging in an Acidic Soil. Carbon, 115, 209-219. https://doi.org/10.1016/j.carbon.2016.12.096

Ren, X., Sun, H., Wang, F., \& Cao, F. (2016). The Changes in Biochar Properties and Sorption Capacities after Being Cultured with Wheat for 3 Months. Chemosphere, 144, 2257-2263. https://doi.org/10.1016/j.chemosphere.2015.10.132

Roberts, K. G., Gloy, B. A., Joseph, S., Scott, N. R., \& Lehmann, J. (2010). Lifecycle Assessment of Biochar Systems: Estimating the Energetic, Economic, and Climate Change Potential. Environmental Science \& Technology, 44, 827-833. https://doi.org/10.1021/es902266r

Saifullah, Dahlawi, S., Naeem, A., Rengel, Z., \& Naidu, R. (2018). Biochar Application for the Remediation of Salt-Affected Soils: Challenges and Opportunities. Science of the Total Environment, 625, 320-335. https://doi.org/10.1016/j.scitotenv.2017.12.257

Sánchez-García, M., Alburquerque, J., Sánchez-Monedero, M., Roig, A., \& Cayuela, M. (2015). Biochar Accelerates Organic Matter Degradation and Enhances N Mineralisation during Composting of Poultry Manure without a Relevant Impact on Gas Emissions. Bioresource Technology, 192, 272-279.

https://doi.org/10.1016/j.biortech.2015.05.003 
Schweiker, C., Wagner, A., Peters, A., Bischoff, W.-A., \& Kaupenjohann, M. (2014). Biochar Reduces Zinc and Cadmium but Not Copper and Lead Leaching on a Former Sewage Field. Journal of Environmental Quality, 43, 1886-1893.

https://doi.org/10.2134/jeq2014.02.0084

Shen, Q., Hedley, M., Camps Arbestain, M., \& Kirschbaum, M. (2016). Can Biochar Increase the Bioavailability of Phosphorus? Journal of Soil Science and Plant Nutrition, 16, 268-286. https://doi.org/10.4067/S0718-95162016005000022

Sika, M. P., \& Hardie, A. G. (2014). Effect of Pine Wood Biochar on Ammonium Nitrate Leaching and Availability in a South African Sandy Soil. European Journal of Soil Science, 65, 113-119. https://doi.org/10.1111/ejss.12082

Silber, A., Levkovitch, I., \& Graber, E. R. (2010). pH-Dependent Mineral Release and Surface Properties of Cornstraw Biochar: Agronomic Implications. Environmental Science \& Technology, 44, 9318-9323. https://doi.org/10.1021/es101283d

Singh, B. P., Hatton, B. J., Singh, B., Cowie, A. L., \& Kathuria, A. (2010). Influence of Biochars on Nitrous Oxide Emission and Nitrogen Leaching from Two Contrasting Soils. Journal of Environmental Quality, 39, 1224-1235.

https://doi.org/10.2134/jeq2009.0138

Soinne, H., Hovi, J., Tammeorg, P., \& Turtola, E. (2014). Effect of Biochar on Phosphorus Sorption and Clay Soil Aggregate Stability. Geoderma, 219-220, 162-167. https://doi.org/10.1016/j.geoderma.2013.12.022

Solaiman, Z. M., \& Anawar, H. M. (2015). Application of Biochars for Soil Constraints: Challenges and Solutions. Pedosphere, 25, 631-638.

https://doi.org/10.1016/S1002-0160(15)30044-8

Solaiman, Z. M., Blackwell, P., Abbott, L. K., \& Storer, P. (2010). Direct and Residual Effect of Biochar Application on Mycorrhizal Root Colonisation, Growth and Nutrition of Wheat. Australian Journal of Soil Research, 48, 546-554. https://doi.org/10.1071/SR10002

Sorrenti, G., Masiello, C. A., Dugan, B., \& Toselli, M. (2016). Biocharphysico-Chemical Properties as Affected by Environmental Exposure. Science of the Total Environment, 563-564, 237-246. https://doi.org/10.1016/j.scitotenv.2016.03.245

Spokas, K. A., Cantrell, K. B., Novak, J. M., Archer, D. W., Ippolito, J. A., Collins, H. P., Boateng, A. A., Lima, I. M., Lamb, M. C., McAloon, A. J., Lentz, R. D., \& Nichols, K. A. (2012). Biochar: A Synthesis of Its Agronomic Impact beyond Carbon Sequestration. Journal of Environmental Quality, 41, 973-989. https://doi.org/10.2134/jeq2011.0069

Steiner, C., Glaser, B., Geraldes Teixeira, W., Lehmann, J., Blum, W. E., \& Zech, W. (2008). Nitrogen Retention and Plant Uptake on a Highly Weathered Central Amazonian Ferralsol Amended with Compost and Charcoal. Journal of Plant Nutrition and Soil Science, 171, 893-899. https://doi.org/10.1002/jpln.200625199

Suliman, W., Harsh, J. B., Abu-Lail, N. I., Fortuna, A.-M., Dallmeyer, I., \& Garcia-Perez, M. (2016). Modification of Biochar Surface by Air Oxidation: Role of Pyrolysis Temperature. Biomass and Bioenergy, 85, 1-11. https://doi.org/10.1016/j.biombioe.2015.11.030

Sun, H., Lu, H., Chu, L., Shao, H., \& Shi, W. (2017). Biochar Applied with Appropriate Rates Can Reduce N Leaching, Keep N Retention and Not Increase $\mathrm{NH}_{3}$ Volatilization in a Coastal Saline Soil. Science of the Total Environment, 575, 820-825.

https://doi.org/10.1016/j.scitotenv.2016.09.137

Thomas, S. C., Frye, S., Gale, N., Garmon, M., Launchbury, R., Machado, N., Melamed, S., Murray, J., Petroff, A., \& Winsborough, C. (2013). Biochar Mitigates Negative Ef- 
fects of Salt Additions on Two Herbaceous Plant Species. Journal of Environmental Management, 129, 62-68. https://doi.org/10.1016/j.jenvman.2013.05.057

Topoliantz, S., Ponge, J.-F., \& Ballof, S. (2005). Manioc Peel and Charcoal: A Potential Organic Amendment for Sustainable Soil Fertility in the Tropics. Biology and Fertility of Soils, 41, 15-21. https://doi.org/10.1007/s00374-004-0804-9

Uchimiya, M., Lima, I. M., Klasson, K. T., \& Wartelle, L. H. (2010). Contaminant Immobilization and Nutrient Release by Biochar Soil Amendment: Roles of Natural Organic Matter. Chemosphere, 80, 935-940.

https://doi.org/10.1016/j.chemosphere.2010.05.020

Ulyett, J., Sakrabani, R., Kibblewhite, M., \& Hann, M. (2014). Impact of Biochar Addition on Water Retention, Nitrification and Carbon Dioxide Evolution from Two Sandy Loam Soils. European Journal of Soil Science, 65, 96-104.

https://doi.org/10.1111/ejss.12081

Van Zwieten, L., Kimber, S., Downie, A., Morris, S., Petty, S., Rust, J., \& Chan, K. (2010a). A Glasshouse Study on the Interaction of Low Mineral Ash Biochar with Nitrogen in a Sandy Soil. Australian Journal of Soil Research, 48, 569-576.

https://doi.org/10.1071/SR10003

Van Zwieten, L., Kimber, S., Morris, S., Chan, K. Y., Downie, A., Rust, J., Joseph, S., \& Cowie, A. (2010b). Effects of Biochar from Slow Pyrolysis of Papermill Waste on Agronomic Performance and Soil Fertility. Plant and Soil, 327, 235-246. https://doi.org/10.1007/s11104-009-0050-x

Verheijen, F., Jeffery, S., Bastos, A. C., Van der Velde, M., \& Diafas, I. (2010). Biochar Application to Soils. Technical Report, European Commission. https://doi.org/10.2788/472

Villalba, J. J., Provenza, F. D., \& Banner, R. E. (2002). Influence of Macronutrients and Activated Charcoal on Intake of Sagebrush by Sheep and Goats. Journal of Animal Science, 80, 2099-2109. https://doi.org/10.1093/ansci/80.8.2099

Wagner, A., \& Kaupenjohann, M. (2014). Suitability of Biochars (Pyro- and Hydrochars) for Metal Immobilization on Former Sewage-Field Soils. European Journal of Soil Science, 65, 139-148. https://doi.org/10.1111/ejss.12090

Wang, J., Xiong, Z., \& Kuzyakov, Y. (2016). Biochar Stability in Soil: Meta-Analysis of Decomposition and Priming Effects. GCB Bioenergy, 8, 512-523.

https://doi.org/10.1111/gcbb.12266

Warnock, D. D., Lehmann, J., Kuyper, T. W., \& Rillig, M. C. (2007). Mycorrhizal Responses to Biochar in Soil-Concepts and Mechanisms. Plant and Soil, 300, 9-20. https://doi.org/10.1007/s11104-007-9391-5

Watarai, S., \& Tana (2005). Eliminating the Carriage of Salmonella Enterica Serovar Enteritidis in Domestic Fowls by Feeding Activated Charcoal from Bark Containing Wood Vinegar Liquid (Nekka-Rich). Poultry Science, 84, 515-521.

https://doi.org/10.1093/ps/84.4.515

Weng, Z. H., Van Zwieten, L., Singh, B. P., Tavakkoli, E., Joseph, S., Macdonald, L. M., Rose, T. J., Rose, M. T., Kimber, S. W., Morris, S. et al. (2017). Biochar Built Soil Carbon over a Decade by Stabilizing Rhizodeposits. Nature Climate Change, 7, 371-376. https://doi.org/10.1038/nclimate3276

Woolf, D., Amonette, J. E., Street-Perrott, F. A., Lehmann, J., \& Joseph, S. (2010). Sustainable Biochar to Mitigate Global Climate Change. Nature Communications, 1, Article No. 56. https://doi.org/10.1038/ncomms1053

Wu, P., Ata-Ul-Karim, S. T., Singh, B. P., Wang, H., Wu, T., Liu, C., Fang, G., Zhou, D., 
Wang, Y., \& Chen, W. (2019). A Scientometric Review of Biochar Research in the Past 20 Years (1998-2018). Biochar, 1, 23-43. https://doi.org/10.1007/s42773-019-00002-9

Xu, G., Sun, J., Shao, H., \& Chang, S. X. (2014). Biochar Had Effects on Phosphorus Sorption and Desorption in Three Soils with Differing Acidity. Ecological Engineering, 62, 54-60. https://doi.org/10.1016/j.ecoleng.2013.10.027

Xu, N., Tan, G., Wang, H., \& Gai, X. (2016). Effect of Biochar Additions to Soil on Nitrogen Leaching, Microbial Biomass and Bacterial Community Structure. European Journal of Soil Biology, 74, 1-8. https://doi.org/10.1016/j.ejsobi.2016.02.004

You, S., \& Wang, X. (2019). Chapter 20: On the Carbon Abatement Potential and Economic Viability of Biochar Production Systems: Cost-Benefit and Lifecycle Assessment. In Y. S. Ok, D. C. Tsang, N. Bolan, \& J. Novak (Eds.), Biochar from Biomass and Waste (pp. 385-408). Elsevier. https://doi.org/10.1016/B978-0-12-811729-3.00020-0

Yuan, J.-H., Xu, R.-K., \& Zhang, H. (2011). The Forms of Alkalis in the Biochar Produced from Crop Residues at Different Temperatures. Bioresource Technology, 102, 3488-3497. https://doi.org/10.1016/j.biortech.2010.11.018

Zhang, D., Pan, G., Wu, G., Wanjiru Kibue, G., Li, L., Zhang, X., Zheng, J., Zheng, J., Cheng, K., Joseph, S., \& Liu, X. (2015). Biochar Helps Enhance Maize Productivity and Reduce Greenhouse Gas Emissions under Balanced Fertilization in a Rainfed Low Fertility Inceptisol. Chemosphere, 142, 106-113.

https://doi.org/10.1016/j.chemosphere.2015.04.088

Zhao, L., Cao, X., Mašek, O., \& Zimmerman, A. (2013). Heterogeneity of Biochar Properties as a Function of Feedstock Sources and Production Temperatures. Journal of Hazardous Materials, 256-257, 1-9. https://doi.org/10.1016/j.jhazmat.2013.04.015

Zheng, H., Wang, Z., Deng, X., Herbert, S., \& Xing, B. (2013). Impacts of Adding Biochar on Nitrogen Retention and Bioavailability in Agricultural Soil. Geoderma, 206, 32-39. https://doi.org/10.1016/j.geoderma.2013.04.018 